\title{
Guarding EU-wide Counter-terrorism Policing: The Struggle for Sound Parliamentary Scrutiny of Europol
}

\author{
Claudia Hillebrand \\ Aberystwyth University
}

\begin{abstract}
Since the terrorist attacks in New York and Washington, DC (2001), Madrid (2004) and London (2005), the European Union (EU) has stepped up its efforts to develop new instruments and reinforce existing ones to fight terrorism jointly. One of the key aspects of the EU-wide fight against terrorism and serious crime is the facilitation and enforcement of information and intelligence exchange among law enforcement authorities and, to a limited extent, security and intelligence services. This article examines how far the EU's commitment to democracy, accountability and transparency is actually fulfilled with respect to its efforts at fighting terrorism by drawing on the example of the activities of the European Police Office (Europol). Taking the European Parliament (EP) and National Parliaments (NPs), but also inter-parliamentary forums, into account, the article analyses how, and to what extent, mechanisms of democratic accountability and, in particular, parliamentary scrutiny are in place to hold EU-wide counter-terrorism actors, such as Europol, to account. This is a particularly timely question given that Europol's parliamentary scrutiny procedures are currently subject to considerable changes due to the change in its legal mandate as of 1 January 2010 and the entry into force of the Lisbon Treaty.
\end{abstract}

\section{Keywords}

Europol; Counter-terrorism; EU internal security; Parliamentary scrutiny; Democratic accountability; Rendition

IN ITS RECENTLY ADOPTED INTERNAL SECURITY STRATEGY (ISS), THE EUROPEAN UNION (EU) re-emphasised its strong commitment to fighting terrorism within its territory (Council of the European Union 2010a). Indeed, counter-terrorism practices are not a purely domestic task anymore. In the aftermath of the terrorist attacks on New York and Washington, DC on 11 September 2001 and subsequent terrorist incidents on European territory, "police institutions across the globe have proliferated their counterterrorism strategies, both domestically and abroad, while international police have likewise stepped up their campaigns" (Deflem 2006a: 241). As a regional actor, the EU quickly identified terrorism as one of the key common threats its member states have to face in the current world (Council of the European Union 2003, 2010a). ${ }^{1}$ The transnational nature of the threat and the realisation that "Europe is both a target and a base for [...] terrorism" (Council of the European Union 2003: 3) are continuously referred to as justifications for increasing counter-terrorism activities at the EU level (for example, Europol 2008: 5). Key features of

\footnotetext{
${ }^{1}$ This article refers to terrorism as defined in Article 1 of the Council Framework Decision of 13 June 2002 on combating terrorism (see Council of the European Union 2002a).
}

Hillebrand, C. (2011). 'Guarding EU-wide Counter-terrorism Policing: The Struggle for Sound Parliamentary Scrutiny of Europol', Journal of Contemporary European Research. Volume 7, Issue 4, pp. 500-519. 
the EU's fight against terrorism are, for example, anti-radicalisation measures, instruments to combat the financing of terrorism, as well as the strengthening and facilitation of information and intelligence sharing between not only police authorities, but also other security providers, such as intelligence services (Spence 2007; Howorth 2008). ${ }^{2}$

While the EU swiftly pushed its counter-terrorism agenda and provided for institutional and mandatory changes, concerns have been raised by parliamentary actors, human rights bodies and a few academic scholars that this development has not been sufficiently accompanied by thorough democratic monitoring and scrutiny of the activities. This article will investigate this claim, focusing on the efforts of the European Police Office (Europol) at fighting terrorism. Europol is well suited for this purpose as it is the only EUwide law enforcement body and it has experienced both an extension of its remits over the years, as well as an increase in financial and personnel resources (see Europol's Annual Reports; House of Commons, Home Affairs Committee 2007: para. 88). Originally set up as an intergovernmental body outside the EU framework, Europol became an EU agency on 1 January 2010. The article will examine how far the EU's continuous emphasis on its commitment to democracy, accountability and transparency in its security policies is actually fulfilled with respect to Europol and EU-wide counter-terrorism policing. ${ }^{3}$ In the context of transnational policing, the EU remains an understudied actor. This article will shed some light on how, and to what extent, mechanisms of democratic accountability and, in particular, parliamentary scrutiny are in place to hold EU-wide counter-terrorism actors, such as Europol, to account. This is a particularly timely question given the recent institutional and quasi-constitutional challenges the EU experienced under the Lisbon Treaty.

The article proceeds as follows. The first section will outline the extent to which the EU, and, in particular, Europol are now involved in activities aimed at fighting terrorism. Based on this exploration, the second section will briefly discuss the need for mechanisms of democratic accountability, and parliamentary scrutiny in particular, with respect to EUwide counter-terrorism policing. To explore the challenges of democratic scrutiny in depth, sections three and four will analyse current forms and tools of parliamentary scrutiny available to the European Parliament (EP) and National Parliaments (NPs) respectively with a particular focus on counter-terrorism policing at the EU level. Completing the picture of the parliamentary scrutiny mosaic, the final section will explore recent debates concerning strengthened inter-parliamentary co-operation in this field.

\section{Europol and EU counter-terrorism policing}

In July 2001, the EP's Committee on Citizens' Freedoms and Rights, Justice and Home Affairs (2001) regretted in a Report the EU's "slowness in responding to the terrorist threat and the fact that there is as yet no coherent and legally binding set of coordinated measures". Two months later, the events of 9/11 had a considerable impact not only on national policing strategies and powers in many EU Member States, but also on the EU. Immediately afterwards, the then Presidency of the European Council (2001) stated that the fight against terrorism ought to become a major policy objective of the Union. The 2010 ISS emphasised that terrorism remains the main common threat to the EU (Council of the European Union 2010a).

\footnotetext{
${ }^{2}$ In this article, the term 'intelligence services' refers to both domestic security services and foreign intelligence services, unless stated otherwise.

${ }^{3}$ Recent references to such values can be found in official documents, such as the Lisbon Treaty, the ISS and the Stockholm Programme (European Council 2010).
} 
The EU's agenda on counter-terrorism has been rightly described as event-driven (see, for example, Coolsaet 2010). The9/11 attacks provoked the EU to prioritise the fight against terrorism as a policy objective. It led, for example, to an EU-wide agreement on a common definition on the term 'terrorism' and the proliferation of initiatives and institutional changes as well as the expansion of functions and mandates of institutions in the area of Justice and Home Affairs (JHA). To tackle terrorism, the European Security Strategy (ESS) called for a broad response to terrorism suggesting "a mixture of intelligence, police, judicial, military and other means" (Council of the European Union 2003: 7). Yet, it was only after the Madrid bombings that the EU's counter-terrorism efforts really "began to come together" (Howorth 2008: 96). The bombings were followed by a Declaration on Combating Terrorism of 15 March 2004, providing for a long-term EU strategy to combat terrorism with a particular focus on the root causes of terrorism. Notably, the Declaration also provided for the expansion of Europol's competences and the establishment of the Joint Situation Centre (SitCen), an intelligence unit which is now part of the European External Action Service. The 2005 EU Counter-Terrorism Strategy finally became the main point of reference for the EU's counter-terrorism efforts, identifying four key areas in which the EU was to become more proactive: 'Prevent' (radicalisation and recruitment), 'Protect' (people and infrastructure from terrorist attacks), 'Pursue' (terrorists) and 'Respond' (to a terrorist attack) (Council of the European Union 2005a).

Given that the EU prioritises a law enforcement approach to terrorism, most of its efforts are located in the field of police and judicial co-operation in criminal matters (PJCC). ${ }^{4}$ Certainly, "large chunks of counterterrorism endeavours in Europe remain principally within the confines of national decision-making" (Coolsaet 2010: 858). That refers, in particular, to sensitive operational matters. There is nevertheless an increasing pressure on security providers to adopt an approach of 'need to share', rather than maintain the traditional approach of 'need to know'. This has become visible in the form of national fusion centres, such as the UK's Joint Terrorism Analysis Centre, where operational intelligence concerning terrorism is collected, analysed and distributed. Yet the 'need to share' does not only refer to the domestic framework, but also to the international realm (Gill and Phythian 2006; Andreas and Nadelmann 2006). Concerning counter-terrorism, logistical, financial and administrative efforts have been made to facilitate such international collaboration.

The EU broadly focuses on the enhancement of communication between counter-terrorist actors at various policy levels. In the operational fields of policing and intelligence, the term communication mainly refers to information and intelligence sharing. For example, the so-called Swedish Framework Decision of 2006 called on national law enforcement authorities to improve their information sharing; and the aim of a 2005 Council Decision was to strengthen the exchange of information concerning terrorist offences (Council of the European Union 2005b, 2006). Collecting and analysing information about suspicious individuals and behaviour is widely understood to be of utmost relevance for detecting terrorist suspects and intervening before the actual criminal offence. Disrupting terrorist networks often depends on "low-level, factual and fragmented" (Gibson 2009: 923) information, including foreign phone numbers, travel records or credit card transactions.

The EU-wide institutional provisions in this field vary immensely. For example, the 2008 Council Decisions concerning the stepping up of cross-border co-operation with a particular focus on counter-terrorism and cross-border crime, based on an international treaty between the governments of Germany, Austria, Belgium, The Netherlands and Spain ('Treaty of Prüm'), allow for the sharing of data among national law enforcement

\footnotetext{
${ }^{4}$ In addition, the EU implemented preventive administrative measures to fight terrorism proactively. Key examples are the establishment of terrorist watch lists, the exchange of Passenger Name Records (PNR) with countries such as the United States (US) as well as the EU's efforts to freeze terrorist assets.
} 
authorities including fingerprints, deoxyribonucleic acid (DNA) samples and vehicle registrations (Council of the European Union 2008a, 2008b). Other forms of bi- as well as multilateral co-operation are more informal and partly take place outside the EU framework (see Den Boer et al. 2008). The most formal example for strengthened cooperation in the field of law enforcement, and counter-terrorism as well, is Europol, the central European-wide law enforcement body based in The Hague.

Europol aims to facilitate the exchange of information and criminal intelligence in the field of law enforcement. The body is bestunderstood as a formal network due to its elaborated liaison system including Europol Liaison Officers (ELOs) seconded from national authorities of the EU Member States but also from non-EU countries and international organisations, such as Interpol. ${ }^{5}$ Europol's central secretariat is located in The Hague and was staffed with 662 people in 2009, including ELOs and personnel directly employed by Europol (Council of the European Union 2010b). In addition to police officers, staff of other law enforcement authorities, customs and intelligence services work at Europol's premises. Europol's budget has been increased from $€ 68.5$ million for 2009 to $€ 92.6$ million for 2010 - which included $€ 12.5$ million to allow for a smooth transition to become an EU agency (Council of the European Union 2010b).

According to its mandate, Europol's overall objective is"to support and strengthen action by the competent authorities of the Member States and their mutual cooperation in preventing and combating organised crime, terrorism and other forms of serious crime affecting two or more Member States" (Council of the European Union 2009a: Art. 3). ${ }^{6}$ To fulfil its mandate, Europol focuses on investigative and analytical intelligence, collects and analyses data from national police agencies and other security authorities and transfers information and intelligence to designated national authorities or EU bodies if necessary. According to its Annual Report covering 2008, Europol (2009) annually supports around "15,000 international investigations into the most significant criminal networks in the EU".

As a network of information exchange, it has only limited capacities to gather information on its own and needs to be provided with data from national agencies (Monar 2006: 503). It nevertheless has its own analysis capabilities - most obviously in form of the criminal intelligence databases titled Analysis Work Files (AWFs), two of which - 'Hydra' and 'Dolphin' - are designated for counter-terrorism. The results of such strategic analyses on different types of crime, including terrorism, are then circulated to EU bodies and national police forces. This also includes the possibility to assist national criminal investigations by the means of information analysis.

Europol's Counter Terrorism Unit, which used to be part of its Serious Crime Department, is now part of Europol's recently established Operations Department (O4). The Unit comprises the areas ofterrorism, illicit trafficking in nuclear and radioactive substances, illicit trafficking in arms, ammunition and explosives as well as racism and xenophobia (Council of the European Union 2005c). Operational and strategic analysis, support to operational investigations at the national level and training of police officials are the main tasks of the Unit. More specifically, it provides a range of analytical products (terrorism threat assessments, 'missing links for ongoing international investigations'); it facilitates information exchange and access to Europol's databases and exchange systems; it can provide expertise 'on-the-spot' through its mobile office and hosts and it maintains several analysis initiatives (Council of the European Union 2010b: point 3.1). The 2009 data for

\footnotetext{
${ }^{5}$ Laurence O'Toole (1997: 445) refers to networks as "structures of interdependence involving multiple organisations. They exhibit some structural stability and include, but extend beyond, formal linkages alone". See also Gerspacher and Dupont (2007) and Deflem (2006b).

${ }^{6}$ The mandate was expressed in a similar manner in Europol's previous mandate, the so-called 'Europol Convention'.
} 
Europol's secure network suggests that 7 per cent of the new cases were related to terrorism (Council of the European Union 2010b: point 2.4). In recent years, it has increasingly developed "more strategic instruments, such as the European Bomb Database and the Early Warning System for explosives and CBRN material" (Council of the European Union 2010a: 8).

Due to the limits that Member States imposed on Europol, it does not have executive police powers. ${ }^{7}$ In the last couple of years, however, various steps have been made towards a more active and operational role of Europol, which led to a discussion about Europol's potential move towards a European Federal Bureau of Investigation (FBl; see Occhipinti 2003; Jeffrey-Jones 2007). Smaller countries such as Austria and Belgium have indeed suggested the establishment of an FBI-like European Police Office, but this was not followed up on (European Report 2005). Nevertheless, there are indications that Europol is slowly transforming into a more operational body and there has been an expansion of its powers. For example, Europol staff can participate in so-called joint investigation teams (JITs) alongside national authorities and it can request individual states to initiate or conduct investigations in specific cases (Council of the European Union 2002b).To improve the EU-wide fight against terrorism, Europol also gained access to other databases of the EU, such as the Schengen Information System (SIS) and the Visa Information System (VIS) database (Council of the European Union 2005d, 2008c).

There is also an external dimension of Europol's co-operative network. Europol can establish and maintain relations with bodies from third countries. The negotiations with the United States (US) after the 9/11 attacks were the most extensive between Europol and a third country so far. They concluded in an agreement in December 2001 on the exchange of both strategic and technical information in the fight against a broad range of serious forms of international crime and the exchange of liaison officers followed by an additional agreement on exchange of data on persons in December 2002 (Europol 2001, 2002). This co-operation was further intensified through a formal liaison arrangement with US law-enforcement agencies. ${ }^{8}$ More recently, as part of the EU-US Terrorism Finance Tracking Programme (TFTP) Europol has become the EU agency responsible for verifying the legality of requests from American counterparts concerning financial data from the SWIFT banking network.

Europol's secure communication channels are also used for other multilateral counterterrorism activities. One example for this is the Atlas group, a grouping of special antiterrorism teams from all $27 \mathrm{EU}$ member states, including the British Special Air Service (SAS) and the French Groupe d'Intervention de la Gendarmerie Nationale (GIGN). While there is little information publicly available about the group, its key aim is to foster cooperation of national counter-terrorist forces, also in order for those forces to be able to support each other in the context of a terrorist incident (European Commission 2007: 9). The forces are meant to strengthen their co-operation "where necessary through organisational and operational arrangements, between Police, Customs, Security Services and Special Forces in the Crisis Management of terrorist incidents" (European Commission 2007: 9).

To conclude, this section has demonstrated the emergence of counter-terrorism policies of the EU over the last decade. Europol continuously strives for a strengthened role in counter-terrorism activities, despite its remaining lack of operational and arrest powers. As Europol's Director recently emphasised in a media interview, that Europol ensured an

\footnotetext{
${ }^{7}$ Article 72 of the TFEU maintains that the ultimate responsibility for the maintenance of law and order and the safeguarding of internal security lies with the Member States.

${ }^{8}$ The Europol-US agreements are examples of the growing external dimension of the AFSJ. In this dimension, the fight against terrorism is also one of the priority areas (see European Commission 2005).
} 
important role in the transatlantic TFTP ought to be understood as yet another indicator that it moves further into "frontline counterterrorist work" (Fidler 2011).

Means of counter-terrorism potentially touch on civil rights and individual freedoms, however. It is therefore a highly political decision to fight terrorism by certain means and not by others, if at all. According to standards of democratic security governance, debates and negotiations about this should not be left to executive, technocratic bodies meeting 'behind closed doors', but such decisions require transparent debates and scrutiny procedures in public forums, such as parliaments (see also Elvins 2006: 36). The following section will therefore explore in how far Europol's counter-terrorism activities have been accompanied by mechanisms of democratic accountability and, in particular, parliamentary scrutiny.

\section{A vacuum of democratic accountability?}

To ensure democratic accountability, parliaments are often understood as the most important accountability holders in democratic regimes (e.g. Bovens 2007). Parliamentary scrutiny ensures the accountability "to a body the majority of whose members are democratically elected and capable of determining the broad direction of policy" (Morgan and Newburn 1997: 80). In general, parliaments are mandated to check the executive and debate and pass laws and therewith "confer democratic legitimacy upon the binding rules that govern the demos" (Tsakatika 2007: 549). They can hold governmental actors to account and provide overall guidance for them. By holding policing bodies to account, parliaments also provide voters with information that allows them to judge the performance of the institution in question. Finally, parliaments also provide the forum to discuss, and decide, what kinds of conduct a society wishes "to declare off-limits" (Peirce 2009).

A lack of sound democratic scrutiny concerning counter-terrorism actors and their performance would appear to be particularly severe, as the activities are of a very sensitive issue and debates about them are intermingled with questions of human rights and individual freedoms. That networks under the EU's umbrella focus on information exchange and data analysis rather than executive functions does not mean that such freedoms and rights cannot be hurt by their work. False or misinterpreted information can impinge on an individual directly. For example, the individuals listed on the EU's so-called terrorist list are directly affected by this administrative act of 'listing' as their financial assets are frozen and they are subject to travel restrictions (Guild 2008). Moreover, information distributed via networks, such as Europol, have been gathered somewhere and their origin, and the means by which they have been gathered, are not always transparent to other network participants. To put it in a nutshell, counter-terrorism might affect human rights and individual freedoms and it is therefore supposed to be governed by strict rules and norms of democratic control.

The experiences of terrorism in various European countries in the late 1960s and throughout the 1970s encouraged co-operation at the European level under the umbrella of the TREVI group in $1975 .{ }^{9}$ The creation of TREVI was the starting point for increasing cooperation with regard to policing, judicial cooperation and mutual assistance in civil and criminal law, formally framed in Title VI ('Police and judicial cooperation in criminal matters') of the Treaty on European Union (TEU) which became effective on 1 November 1993. Since then, the area has been characterised by a "restless institutional dynamic" (Walker 2004: 14), further pushed by the Treaty of Amsterdam in 1997 calling for the creation of the AFSJ. The area grew in impressively short time both in terms of functions

\footnotetext{
${ }^{9}$ TREVI refers to 'Terrorisme, Radicalisme, Extremisme, Violence Internationale'.
} 
and in terms of institutional capacity, comprising diverse policy aspects and institutions. As a consequence, the AFSJ is understood as being complex, ambiguous and opaque (Guild and Carrera 2005: 2).

Article 67of the Treaty on the Functioning of the European Union (TFEU) maintains an explicit mandate for the EU to provide a high level of security for its citizenry. The tools of providing security through information-sharing networks such as Europol raise concerns, however, about the relationship between the citizens - for whom security is provided and the networks as the security providers. It appears that the bonding between the citizens and the practices of transnational counter-terrorism policing is a fragile and barely existing one. The Third Pillar was of an intergovernmental nature, i.e. the decision-making processes remained in the hands of member-states' governments. While the Lisbon Treaty merged the acquis of the Third Pillar with that of the Community and therefore provides for ordinary supranational EU decision-making procedures with respect to most matters of $\mathrm{JHA}$, operational police co-operation is one of the issues that remain subject to the unanimity in the Council and where the EP has only to be consulted (General Secretariat of the Council of the EU 2009). In addition, the Treaty allows for enhanced co-operation with respect to police work. Due to the strong role of the executive in this policy field, citizens have only limited and rarely direct impact on the field. This is intensified by the general problem that transnational policing has only "low public visibility" (Loader 2002).It is therefore likely that accountability and transparency in this field remain problematic under the Lisbon Treaty. Certainly, this is in sharp contrast to the original idea of the creation of the AFSJ which "was to be based upon the principles of transparency and democratic control, as well as upon an open dialogue with civil society in order to strengthen the acceptance and support of citizens" (Eder and Trenz 2003: 113; European Council 1999). Moreover, the Third Pillar has been well-known for its technocratic policy-making approach "whereby decisions are de-politicised through being placed in the hands of law enforcement 'experts' to develop ideas and legitimising discourse for political elites. Such bodies do not have to justify either the basis of those decisions, or their implications, to national democratic structures" (Elvins 2006: 36-37). With respect to Europol, this approach became in particular obvious in the debate about the Europol-USA agreements on the exchange of data and liaison officers.

The following two sections will explore the parliamentary scrutiny of Europol, and the EU's counter-terrorism activities more broadly, focusing on the EP (section 3 ) as well as the role of NPs (section 4). The sections will analyse the struggle for sound parliamentary scrutiny of Europol over time, taking into account the recent changes caused by the transfer of Europol from a body based on an international treaty to an EU agency. While Europol remains politically accountable to the Council, and Europol's Director is accountable to Europol's Management Board comprising one representative from each Member State, and the Commission, the arrangements of parliamentary scrutiny are far more complex.

\section{Scrutinising Europol at the EU level: the role of the European Parliament}

Given Europol's mandate and range of activities, scrutiny through the EP appears to be a crucial feature of its oversight system. Yet, the EP's powers were strictly limited with respect to policing before the entry-into-force of the Lisbon Treaty. Overall, "European internal security cooperation [was] characterised by the disinclination of the Union's interior ministers and their officials to subject themselves to robust parliamentary input" (McGinley and Parkes 2007: 245). The TEU excluded the EP, but also its national counterparts, from any serious role concerning matters of policing. Although the Treaty of Amsterdam provided the EP with a few more competencies concerning the Third Pillar, the Council continued to hold most of the power in this area. The case of Europol was no exception (Occhipinti 2003: 68; Anderson 1995: 254). Moreover, the EP had merely 
consultative powers with respect to the implementation process of the EU's emerging counter-terrorism policy (Monar 2005: 450). It was also completely excluded from the two agreements between the EU and the US on extradition and mutual legal assistance in criminal matters on 25 June 2003 (Monar 2004: 406). The governments of the EU Member States kept their sovereignty in this area as much as possible.

Despite the fact that the lack of parliamentary scrutiny had long been criticised by civil rights activists, parliamentarians and others, the national governments - in form of the Council of Ministers -were deeply reluctant to allow a stronger role for parliaments in this area. The key reason was their desire to keep full control over this area. Consequently, the Council, but also the European Commission, used to involve the EP only when absolutely necessary. Article 39 of the TEU required the Council to consult the EP before the adoption of any legally binding measures in this field (e.g. decisions, framework decisions and conventions). That included, for example, decisions regarding the development of Europol, but it excluded any priority setting. Moreover, such a consultation procedure had no binding effects for the Council "whereas parliaments in the Member States must approve rules governing the functioning of national agencies" (Apap 2006: 3). Even when it came to the adoption of the Council Act of November 2002 regarding the crucial Protocol to amend the Europol Convention and the Protocol on the privileges and immunities of Europol, the members of its organisations, the deputy directors and the employees, a lack of consultation was stated by MEPs. All in all, at least three key challenges to parliaments can be identified in the specific context of Europol's work: there is a lack of regular reports on police cooperation between national authorities, the reports provided by Europol contain insufficient information to assess effectiveness and appropriateness of its activities and there is no independent assessment of Europol's operations (Peers 2005: 202).

Given these serious limitations of parliamentary scrutiny with respect to Europol, several academic scholars, policy-makers and police practitioners suggested improvements concerning the democratic control of Europol in general and its parliamentary oversight in particular (see, for example, Bruggeman 2006; House of Lords 2003; Apap 2006; Puntscher Riekmann 2008). Some of these have been included into the Lisbon Treaty which, overall, strengthens Europol's parliamentary scrutiny. However, that the national governments were keen on keeping the EP excluded from decision-making with respect to Europol for as long as possible became apparent briefly before the Lisbon Treaty took effect. The Treaty would abolish the EU's pillar system and, constituting one single legal framework, provide for co-decisive and consent powers for the EP. ${ }^{10}$ According to Article 68 TFEU, the European Council could set "strategic guidelines for legislative and operational planning", but the EP was nevertheless to be involved in the legislation process. Therefore, at a time when the Treaty of Lisbon was agreed on but not yet ratified fully, the governments of the Member States ratified and implemented some important protocols which were necessary in order to agree on a Decision replacing the Europol Convention. If they would not have found an agreement and the Treaty of Lisbon would have entered into force quickly, such a regulation would have had to be negotiated with the EP (see also Monar 2008: 121).

A similar situation emerged in late 2009. On 25 November 2009, the EP rejected four proposals concerning Europol which had been tabled by the Council with regard to Europol's AWFs, the confidentiality of its information, its exchange of personal data with partners and its agreements with third countries. Again, the timing is crucial to understand the Council's attempts to avoid parliamentary involvement in matters of policing. By the time the Council presented the proposals to the EP, the provisions of the TEU required the

\footnotetext{
${ }^{10}$ There are severe limitations to the EP's role given special provisions on several issues concerning police and judicial co-operation. In particular, operational co-operation among national law enforcement authorities is an area in which the EP will continue to have a consultative role only.
} 
Council only to take the opinion of the EP into account (which in practice meant that it could ignore it). Had the proposals been tabled only one week later, the Lisbon Treaty would have been entered into force and the EP would have had the powers of full codecision making on these issues. The EP criticised the Council's rush of the decisions sharply (European Parliament 2009). Nevertheless, the JHA Council ignored this criticism and adopted the four proposals during a meeting on 30 November - one day before the Lisbon Treaty became effective (Council of the European Union 2009b, 2009c, 2009d, 2009e).

Yet the EP has not been entirely 'toothless' in the field of PJCC. For example, the EP increased its influence in these matters over time through so-called issue linkages. Since the Parliament's approbation was necessary for First Pillar legislation, it sometimes agreed on a legal instrument only under the condition that its opinion would be considered seriously with respect to a certain Third Pillar measures. Such was the case concerning the debate about the VIS, for example (McGinley and Parkes 2007: 248).

Also, the investigation into the European involvement in the CIA's extraordinary rendition programme must be understood as a counter-terrorism feature where the EP acted as a substitute at a time when NPs were not sufficiently safeguarding their role as accountability holders (Hillebrand 2009). Following an investigation by the Council of Europe into the involvement of European countries in cases of extraordinary rendition, the EP used its powers to set up aTemporary Committee on the alleged use of European countries by the CIA for the transport and illegal detention of prisoners (TDIP) (European Parliament, TDIP 2007; see also Council of Europe Parliamentary Assembly 2006, 2007). The collection of information appeared to be a challenging task, partly because some EU bodies were reluctant to assist the work of the TDIP Committee. As a consequence, the final report bluntly criticised the lack of co-operation of individual EU officials and institutions in the investigation, including the refusal of the then Director of Europol, MaxPeter Ratzel, to appear before the Committee.

Given the limited role of the EP in the intergovernmental decision-making processes within the Third Pillar and with respect to Europol in particular, it pushed initiatives to change Europol's legal basis for some time. Most notably, in a 2003 Resolution on Europol's Future Developments it suggested to replace the existing Europol Convention with a Council decision so that decisions relating to Europol would no longer be taken by the Council acting unanimously but would need to be adopted by qualified majority and by co-decision with the EP (European Parliament 2003). The EP also required to be "provided with the legal means and institutional framework to enable it in the future to exercise genuine democratic control" (Apap 2006: 4).

The transfer from an intergovernmental institution to an EU agency also meant that Europol would lose autonomy and that its (semi-)operational powers could be easier expanded at the same time. This led the 2006 Finnish EU-Presidency to table the improvement of Europol's legal framework, and the JHA Council on 4-5 December 2006 agreed to replace the Europol Convention by a Council Decision. The Commission quickly provided a draft decision, but a consensus on the final wording of the Council decision establishing Europol was only reached some 15 months later at a Meeting of the JHA Council on 18 April 2008 (see Amici 2010: 82-83). The final Decision was adopted on 6 April 2009 and has been effective as of 1 January 2010 (Council 2009a).

This 2009 Council Decision includes substantial changes concerning Europol's mandate and its powers. Up to the end of the year 2009, Europol operated outside the EU Treaty, but the Council Decision transferred Europol into an entity of the EU. That implies that European Community action rules now apply to Europol. Crucially, the EP is now involved in controlling and overseeing Europol's budget (Art. 43(6), (9) and (10) Council Decision). 
This change had an impact on the EP's powers to gather more information directly from Europol, as "Europol is also obliged to submit to the EP, at the latter's request, any information required for the smooth application of the discharge procedure for the financial year in question" (European Commission 2010: 7).

The new Council Decision also maintains that the adaption of the Council Decision strengthens the role of the EP with respect to Europol's scrutiny, as the Parliament has the general right to be heard in respect to all implementing measures based on a Council decision. More explicitly, Article 88 of the TFEU maintains that the EP will now "determine Europol's structure, field of action and tasks" in co-decision with the Council.

So far, however, practices appear not to have changed substantially. Over time, the EP as a whole and in particular members of its LIBE Committee have pointed out again and again the marginalisation of the EP with respect to EU security matters. For example, in the context of developing and implementing the ISS a recent working document of the LIBE Committee criticised the "disregard shown to date by the Commission and Council for the role of the European Parliament and national parliaments in drawing up this strategy. [...] Incredible as it may appear, the principal strategic documents adopted to date by the European Council, the Council and the Commission seem to ignore the existence of the European Parliament altogether" (European Parliament, LIBE Committee 2011: 4). Crucially, the Commission was criticised for effectively delaying the 'Lisbonisation' of Europol, despite the EP's clearly signalised priority of this matter (European Parliament, LIBE Committee 2011).

While the EP remains struggling to ensure a stronger position within Europol's oversight system, the Commission, in contrast, continuously emphasised that "the opportunities for scrutiny of Europol by the European Parliament are 'legally appropriate"' and that it "would not support deeper involvement by, for example, including provision in a future Regulation for the European Parliament to designate members of Europol's Management Board or to participate in the appointment of Europol's Director" (European Commission 2010b: point 10.11). The Commission justified that decision with the limited powers and autonomy of Europol. National executives tend to support the Commission's stance. For example, the UK Minister of Crime Prevention argued that "in order to protect Europol's political independence, there should be no role for the European Parliament on Europol's Management Board or in appointing Europol's Director" (House of Commons, EU Committee 2011).

While it appears that the recent changes of Europol's legal footing and institutional role within the EU have brought about several improvements concerning the EP's scrutiny powers with respect to Europol and, overall, strengthened the parliamentary scrutiny at EU level, the following section will draw the attention to parliamentary scrutiny procedures at the national level.

\section{Scrutinising Europol at the national level: the role of national parliaments}

The network perspective on Europol, suggested at the beginning of this article, refers to strong linkages between Europol's central secretariat and national law enforcement authorities in the Member States - most notably through Europol's liaison system. This structure calls for a crucial involvement of all NPs in Europol's parliamentary scrutiny landscape. From a perspective of democratic governance, scrutiny through NPs is important as it directly links the elected parliaments with the EU system (Guild and Carrera 2005: 4). In Europe, police and intelligence authorities and their activities are overseen and controlled within the domestic framework. Since they are bodies with executive functions, the scrutiny of the governments through their national parliaments is a key mechanism. 
Parliamentary scrutiny is also one element of the traditional checks on executive law enforcement powers in terrorism investigations. Finally, some authors argue that the main problems with regard to the EU's overall democratic legitimacy remain at the national level and should therefore be tackled at that level as well (e.g. Muller-Wille 2006).

Detailed comparative information about the ways in which NPs scrutinise matters of EUwide police co-operation is hard to find. A rare exception is the questionnaire that the Secretariat of the Conference of Community and European Affairs Committees of Parliaments of the European Union (COSAC) circulated in 2008 among NPs to inquire into their scrutiny procedures of the Schengen process (i.e. the measures included in the Schengen Agreement, as well as the enlargement of the Schengen Area) (COSAC 2008: Annex). The questionnaire was driven by the question as to whether the particular sensitivity of the issues, which were touching on questions of asylum, security and individual freedoms, had pushed the NPs to reinforce their general scrutiny procedures of EU policies in this particular area (COSAC 2008: ch. 4 and Annex). The result was that most NPs continued to use their normal scrutiny procedures, which are usually not binding for the government in question. Several parliaments have strengthened their monitoring efforts concerning matters related to the AFSJ. In the German Bundestag, for example, "the scrutiny of EU-documents relating to the Schengen area is firstly scrutinised by the Internal Affairs Committee, then the European Affairs Committee and finally in the plenary. The Federal government has to report before and after the meetings of the Justice and Home Affairs Council to the Internal Affairs Committee on the different aspects of the Schengen acquis and on the enlargement of the Schengen area"(COSAC 2008: 39). Few countries have substituted their normal scrutiny procedures by special arrangements for Schengen issues (for example, Italy created a bicameral committee on Schengen and Europol).

Despite such provisions, the role of NPs in the field of European police co-operation is criticised from various sides. One problem is that decision-making at EU level tends to exclude NPs in the early stage of policy-shaping and decision-making. ${ }^{11}$ Concerning procedures of parliamentary scrutiny, Monar (2008: 120) argued that there is a "problem of ineffective national parliamentary scrutiny procedures that have difficulties to cope with the increasing volume of JHA legislation". That leads to delays in ratifying regulations which have been agreed at EU level. Another problem was raised by an MEP in an anonymous interview with the author in March 2008. Asked about the co-operation between the EP and NPs concerning the AFSJ, they criticised that the NPs are very much focused on national matters and would not feel responsible for the scrutiny of the EU's (then) Third Pillar (Interview A). An expert in the field of data protection in the Third Pillar also expressed their impression that NPs have no time, do not take the time, have no interest or do not prioritise the area of police co-operation (Interview B). Given such limitations and restrictions, the general role of the NPs concerning police co-operation has been described as a 'non-role' (Lodge, 2007). Other observers have, however, argued that, in contrast to the EP, NPs often "had better opportunities to influence the legislation processes in the third pillar, due to the unanimity requirement" (Lummer 2008).

Concerning Europol, NPs used to be involved in the ratification process concerning the proposals to amend the Europol Convention and the Protocols thereto. Such a national ratification process could push the involvement of NPs to explore Europol's work (Peers 2005: 203). Moreover, NPs have the powers to oversee their national representatives on Europol's Management Board. These representatives do not report directly to their Parliament, however, but to their respective Government Minister and, as the collective board, to the Justice and Home Affairs Council. The national ministers are then answerable to their parliaments.

\footnotetext{
${ }^{11}$ For the problem of 'de-parliamentarisation' in general see Börzel (2000).
} 
Up to the entry into force of the Europol Council Decision, the role of NPs concerning issues related to Europol was not clearly regulated. Art. $34 \$ 3$ of the Europol Convention only pointed to the fact that the Member States' governments should deal with the parliamentary role individually. As a consequence, NPs were usually not involved in any of the agreements that Europol negotiated with third parties (such as the two Europol-USA agreements discussed above). Their involvement was limited to the ratification process of proposals for amending the Europol Convention and the Protocols thereto. In this process, they did not have an impact on the text, but only decide whether or not they want to ratify the amendment. For example, when the Europol Convention - Europol's previous legal base - was originally established, neither the EP nor the NPs were consulted in the negotiations or the process of the drafting of the Convention. When questioned about the involvement of parliament in drafting and approving the Convention in the British House of Commons on 11 January 1996, the then British Home Secretary, Michael Howard, replied in writing as follows: "The final text of the Europol convention was published, and laid before Parliament, on 8 December last year. Drafts of the convention were not public documents and therefore were not published nor made generally available" (House of Commons 1996). Tellingly, he added that "[t]he police service were closely consulted throughout the negotiation of the convention through police representative organisations" (House of Commons 1996). Thus, while parliaments and the wider public were not involved in the negotiations at all, executive authorities were much more so. Moreover, the ratification process of the Europol Convention provided the NPs with no power to amend the text. This is a crucial basic problem with respect to Europol since, as Aden (2001: 112) stated, "[o]nce established, international bureaucratic institutions such as Europol will leave little scope to be reshaped by democratic institutions".

In 2002, the Dutch Parliament circulated a questionnaire among the parliaments of the then EU Member-States to understand how other NPs dealt with the subject of Europol (Fijnaut 2002). Though few countries replied, it became clear that at that point "Europol [was] usually only discussed in meetings - plenary sessions or meetings of special committees - concerning the European Union or the Third Pillar in general" (Fijnaut 2002: 18). Also, it appeared that parliamentary chambers found it difficult to assess Europol's work. However, several NPs across Europe had mechanisms in place to examine Europol's budget and the protocols, which amend the Convention (see COSAC 2005: 89-94).

Up to today, NPs primarily examine Europol's performance "through their control over their respective governments, in accordance with the constitutional rules of each Member State" (European Commission 2010: 8). Crucially, NPs supervise the work of the minister responsible for policing, and therefore also Europol. However, the recent transfer of the Europol Convention by a secondary EU law act in 2009 carries the danger that NPs might no longer be directly involved in future changes to Europol's legal framework. Future amendments to the Europol Council Decision only require a qualified majority voting in the Council. This appears to be a considerable loss of powers for NPs as the ratification process of changes to Europol's statutory footing was one of the few ways through which NPs were involved in Europol's scrutiny (Lavranos 2003: 261). This way NPs were able to "influence decisions at EU level by pressuring their governments to veto a certain law" (Lummer 2008). The involvement of parliaments should not be limited to the approval of a convention anyway, however. Instead, they should already be engaged during the preparation process so they could have an impact on the content of agreements. In a similar vein, a report on Europol by the House of Lords (2003) pledged for a strong role of the NPs in the accountability procedure of Europol.

Paradoxically, certain aspects of the TFEU suggest a potentially strengthened role for NPs. In general, NPs are called on to "contribute actively to the good functioning of the Union" (Art. 12 TFEU). More specifically, the Treaty explicitly calls for NPs to engage with issues 
concerning the AFSJ (for example, by ensuring that EU legislation in this area respects the principle of subsidiarity). With respect to Europol, NPs are to be involved in the "political monitoring" (Art. 12(c) TFEU) of its activities. However, the wording of the TFEU in this respect is vague and it remains to be seen which mechanisms NPs will use to fulfil their new mandate. Moreover, under the Lisbon Treaty, NPs receive from the Commission any draft legislative act at the same time as it is transmitted to the EP and the Council. They are asked to verify the latter's compliance with the principle of subsidiarity and, depending on the national constitutional procedures, have the right to state an opinion (Art. 12 TEU; European Commission 2010: 20-21).

What remains a particular concern are intergovernmental arrangements concerning counter-terrorism policing outside the EU framework. Guild and Geyer (2006) argued, for example, that NPs "are not able to guarantee democratic control over purely intergovernmental agreements." A crucial example was the ratification procedure of the Prüm Treaty in the German Bundestag in May 2006. The government did not give the Bundestag a fair chance to influence the outcome as it granted only "some weeks for parliamentary scrutiny - including committee work" (Guild and Geyer 2006). ${ }^{12}$ Similarly, the external dimension of Europol's network raises concerns. The two Europol-US Agreements of 2001 and 2002 - referred to earlier in this article - became directly binding law, but they did not involve the EP or NPs in any meaningful sense. Consequently, the UK House of Lords Select Committee (2003: 17) criticised the second EU-US Agreement for having "in effect been settled with the United States authorities before it was deposited for scrutiny."

As the scrutiny performance of the EP and, in particular, the NPs remains unsatisfactory on many accounts, some called for the parliaments to pool their powers and resources or to, at least, co-ordinate their work in this context better. To complete the picture, the final section will briefly explore the main discussion points.

\section{Towards a combined effort?}

The remaining shortcomings of parliamentary scrutiny led several observers to call for increased co-operation between NPs and the EP in order to ensure a high degree of scrutiny of Europol. A close co-operation between NPs and the EP has also to be welcomed from a network perspective, given the interwoven structure of Europol's various 'nodes'.

While there have been early attempts to establish a joint committee previously (e.g. European Commission 2002), such an option is dramatically facilitated by regulations under the Lisbon Treaty. In particular, Article 88(2) TFEU calls for co-ordination between the EP and NPs in scrutinising Europol. In principle, three institutional arrangements are on the table. Firstly, a strengthened role for an existing inter-parliamentary body, namely COSAC, which already has some experience with respect to matters related to the AFSJ. Secondly, a more informal option would be the use of existing inter-parliamentary meetings of MEPs as well as national MPs. And finally, a third option would be to create a new Joint Committee comprising of representatives of the EP and the NPs (possibly drawn from existing specialist committees).

Interestingly, the Commission has taken a strong stance in favour of the third option. In late 2010, the Commission circulated a Communication on the procedures for the parliamentary scrutiny of Europol's activities (European Commission 2010b). In it, the

\footnotetext{
12 See also the criticism of the lack of time and influence concerning the first Europol-US Agreement on the transmission of personal data in the 2003 House of Lords Report on Europol.
} 
Commission expressed dissatisfaction with the existing arrangements and called for the creation of a joint body or inter-parliamentary forum, comprising the relevant members of NPs and the EP, which would meet on a regular basis. Doing so would ensure "unifying parliamentary control at European Union level (without prejudice to national parliamentary procedures)" (European Commission 2010b: 15). It would also enable a smoother information transfer on Europol to NPs.

A few NPs have quickly raised concerns about the proposal. The Commission Communication was discussed by the EU Select Committee of the House of Commons in February 2011, for example. It came to the conclusion that the suggested joint Committee would operate on a European, rather than the national level, and "would cover aspects of Europol's strategic planning and activities" which the House of Commons' Committee "would not routinely consider" (House of Commons, EU Committee 2011). It also emphasised that "any views expressed within the framework of inter-parliamentary cooperation should not bind national parliaments or prejudge their positions" (House of Commons, EU Committee 2011). Moreover, the UK Minister for Crime Prevention, James Brokenshire rejected the idea, not seeing any additional value of such a body (House of Commons, EU Committee 2011). He pointed to the 2008 report by the House of Lords European Union Committee which maintained that such a joint Committee comprising representatives of 27 member states would be likely to be unworkable.

The Commission's course of action in this matter hit a sensitive spot for parliamentary actors, threatening their self-understanding of independent authorities. As the House of Commons EU Committee (2011) explicitly stated, "it is for the European Parliament and national parliaments to determine together how to organise and promote effective and regular inter-parliamentary cooperation." This is in accordance with Art. 9 of the Protocol (No 1) to the new Treaties on the role of NPs, which maintains that the EP and NPs "shall together determine the organisation and promotion of effective and regular interparliamentary cooperation within the Union."

The idea of a joint committee, or strengthened inter-parliamentary scrutiny mechanisms, crucially depends on the willingness of the parliamentarians in question to engage with each other. As the discussion by the EU Committee above suggests, NPs might fear a power drain from the national to the EU level. As a consequence, NPs appear to slowly wake up to the need of becoming more actively involved in the discussion. At a recent meeting of the speakers of the NPs, the representatives also discussed the 'Role of the Parliaments in the Monitoring of the European Freedom, Security and Justice'. For example, they discussed plans for the creation of a database which would allow parliamentary committees to exchange information concerning parliamentary oversight of the security and intelligence services (Federal Parliament of Belgium 2011). The creation of a 'European Network of National Intelligence Reviewers' by setting up a website was supported by the participants. More specifically, the speakers discussed the existing parliamentary mechanisms to monitor Europol's activities in the light of the Commission's communication. They considered the current forms of scrutiny to be insufficient and suggested "that scrutiny should be exerted by an interparliamentary body within which representatives of the national parliaments and the European Parliament would meet on a regular basis" (Federal Parliament of Belgium 2011). While details of form, mandate and structure of such co-operation remained unclear, it was suggested to organise the scrutiny "within the framework of the existing interparliamentary structures" (Federal Parliament of Belgium 2011).

While strengthened co-operation concerning the parliamentary scrutiny of Europol will remain the subject of discussions for some time, the Commission provided a clear timeframe, as it aims to integrate detailed mechanisms of parliamentary scrutiny into a new legal framework for Europol (expected to be based on an EU Regulation) in 2013. 


\section{Conclusion}

In most European countries, counter-terrorism activities are now regulated by special legislations which provide both police and intelligence authorities with special powers and means. At the same time, current counter-terrorism activities include procedures of information gathering and sharing across borders. The EU is an emerging actor in the field of counter-terrorism policing, though its powers are still very limited in comparison to national authorities. Yet, transnational threats, and the networked response by security providers, "put into question the foundations of a security system based on the norms of national sovereignty and a state monopoly of the legitimate use of violence" (Krahmann 2005: 204). This development also causes challenges with respect to the democratic scrutiny of current transnational forms of security provision. This article was concerned with policing efforts via EU-wide networks in the field of counter-terrorism, which are tasked with the facilitation and enhancement of information and intelligence sharing, focusing on the case of Europol.

The analysis of the responsibilities and powers of parliaments scrutinising Europol provided above provides a complex picture of the existing accountability and oversight landscape. At the time of writing this article, Europol's legal framework and scrutiny procedures are still "the subject of an ongoing reflection" (European Commission 2010b: 5). The article demonstrated that the scrutiny mechanisms have been changed several times since the creation of Europol, but the recent changes under the Lisbon Treaty as well as due to Europol's new legal framework are the most dramatic ones. The analysis demonstrated that the EP has come a long way from a consultative body to a co-legislator in this field. The Parliament's scrutiny powers have been strengthened, overall. The picture is more blurred when it comes to the role of the NPs, in particular due to changes in Europol's ratification procedures. Neither the EP nor the NPs have been able to make full use of their new powers and rights so far, however, and currently seem to be in the process of 'soul-searching' in this respect. In general, it will remain difficult for parliamentary scrutiny bodies in this field to "show their muscle as the voice and guardian of the people" (Lodge 2004: 254). Any engagement in the field of police co-operation is hampered by various factors. In particular, the network-like transnational structure, the multitude of actors involved and the overall secrecy of the field pose crucial challenges.

An important improvement would be an improved co-operation among parliamentary actors at both the EU and the national level. While the final section of the article outlined the challenges of creating any inter-parliamentary forum, such a body would allow parliamentary actors to compare their 'best practices' and problems in this field and to pool their investigative efforts with respect to EU-wide policing, and Europol in particular. At a time when internal security has become a fully-fledged policy matter under the Lisbon Treaty, the EU has confirmed its commitment to values such as democracy, transparency and accountability. However, as ongoing debates about the new ISS suggest, there remains a mismatch of those normative claims and the EU's everyday practices (House of Lords, European Union Committee 2011). Taking on an active role in negotiating their scrutiny rights and procedures, the NPs could make a constructive contribution to a strengthened democratic accountability of the EU in this field. 


\section{References}

Aden, Hartmut (2001) 'Convergence of Policing Policies and Transnational Policing in Europe', European Journal of Crime, Criminal Law and Criminal Justice 9, 2, 99-112.

Amici, Victoria (2010) 'Europol et la nouvelle decision du Conseil: entre opportunités et contraintes', Revue du Droit de I'Union Européenne 1, 77-99.

Anderson, Malcolm (1995) 'Controlling European Police Institutions', in Policing the European Union, ed. by Malcolm Anderson et. al., Oxford: Clarendon Press, 250-278.

Andreas, Peter and Nadelmann, Ethan (2006) Policing the Globe, Oxford: Oxford University Press.

Apap, Joanna (2006) 'Session 2: What Future for Europol?: Increasing Europol's Accountability and Improving Europol's Operational Capacity', European Parliament, DG Ipol, Policy Department C - Citizens Rights and Constitutional Affairs, Brussels, 7 September 2006.

Bignami, Francesca (2007) 'Towards a right to privacy in transnational intelligence networks', Michigan Journal of International Law 28, 3, 663-686.

Börzel, Tanja (2000) 'Europäisierung und innerstaatlicher Wandel: Zentralisierung und Entparlamentarisierung?', Politische Vierteljahresschrift 41, 225-250.

Bovens, Marc (2007) 'New Forms of Accountability and EU Governance', Comparative European Politics 5, 1, 104-120.

Bruggeman, Willy (2006) 'What are the options for improving democratic control of Europol and for providing it with adequate operational capabilities?', Briefing Paper, European Parliament, DG Ipol, Policy Department C - Citizens Rights and Constitutional Affairs, 16 February 2006, Brussels, Doc. IP/C/LIBE/FWC/2005-24.

Coolsaet, Rik (2010) 'Counterterrorism Strategy: Value Added or Chimera?', International Affairs 86, 4, 857-73.

Conference of Community and European Affairs Committees of Parliaments of the European Union (COSAC) (2005) 'Third bi-annual Report: Developments in European Union Procedures and Practices Relevant to Parliamentary Scrutiny', prepared by the COSAC Secretariat, May 2005, Brussels.

Conference of Community and European Affairs Committees of Parliaments of the European Union (COSAC) (2008) 'Ninth bi-annual Report: Developments in European Union Procedures and Practices Relevant to Parliamentary Scrutiny', prepared by the COSAC Secretariat, May 2008, Brussels.

Council of Europe Parliamentary Assembly, Committee on Legal Affairs and Human Rights (2006) 'Alleged secret detentions and unlawful inter-state transfers of detainees involving Council of Europe member states', Report by Rapporteur, Doc. 10957, 12 June 2006, Strasbourg.

Council of Europe Parliamentary Assembly, Committee on Legal Affairs and Human Rights (2007) 'Secret detentions and illegal transfers of detainees involving Council of Europe member states: second report', Report by Rapporteur, Doc. AS/Jur (2007) 36, 7 June 2007, Strasbourg.

Council of the European Union (2002a) 'Council Framework Decision of 13 June 2002 on combating terrorism', Doc. 2002/475/JHA, OJ L 164, 22 June 2002.

Council of the European Union (2002b) Council Framework Decision of 13 June 2002 on joint investigation teams', Doc. 2002/465/JHA, 20 June 2002.

Council of the European Union (2003) 'A secure Europe in a better world: the European Security Strategy', Brussels, 12 December 2003.

Council of the European Union (2005a) 'The European Union Counter-Terrorism Strategy', Brussels, JHA Council, 1-2 December 2005.

Council of the European Union (2005b) 'Council Decision 2005/671/JHA of 20 September 2005 on the exchange of information and cooperation concerning terrorist offences', OJ L 253/22, 29 September 2005. 
Council of the European Union (2005c) 'EU Plan of Action on Combating Terrorism Update', Note from Europol to Council, Council Doc. 9156/05, Brussels, 23 May 2005.

Council of the European Union (2005d) 'Council Decision 2005/211/JHA of 24 February 2005 concerning the Introduction of Some New Functions for the Schengen Information System, Including in the Fight Against Terrorism', OJ 68/44, 15 March 2005.

Council of the European Union (2006) 'Council Framework Decision 2006/960/JHA of 18 December 2006 on simplifying the exchange of information and intelligence between law enforcement authorities of the Member States of the European Union', OJ L 386, 29 December 2006.

Council of the European Union (2008a) Council Decision 2008/615/JHA of 23 June 2008 on the stepping up of cross-border cooperation, particularly in combating terrorism and cross-border crime', OJ L 210/1, 6 August 2008.

Council of the European Union (2008b) 'Council Decision 2008/616/JHA of 23 June 2008 on the implementation of Decision 2008/615/JHA on the stepping up of crossborder cooperation, particularly in combating terrorism and cross-border crime', OJ L 210/12, 6 August 2008.

Council of the European Union (2008c) 'Council Decision 2008/633/JHA of 23 June 2008 concerning access for consultation of the Visa Information System (VIS) by designated authorities of Member States and by Europol for the purposes of the prevention, detection and investigation of terrorist offences and of other serious criminal offences', OJ L 218/129, 13 August 2008.

Council of the European Union (2009a) 'Council Decision of 6 April 2009 establishing the European Police Office (Europol) (2009/371/JHA)', OJ L 121/37.

Council of the European Union (2009b) 'Council Decision 2009/934/JHA of 30 November 2009 adopting the implementing rules governing Europol's relations with partners, including the exchange of personal data and classified information'.

Council of the European Union (2009c) 'Council Decision 2009/935/JHA of 30 November 2009 determining the list of third States and organisations with which Europol shall conclude agreements'.

Council of the European Union (2009d) 'Council Decision 2009/936/JHA of 30 November 2009 adopting the implementing rules for Europol analysis work files'.

Council of the European Union (2009e) 'Council Decision 2009/937/09 of 30 November 2009 adopting the rules on the confidentiality of Europol information'.

Council of the European Union (2010a) 'Draft Internal Security Strategy for the European Union: 'Towards a European Security Model', Doc. 5842/2/10, Brussels, 23 February 2010.

Council of the European Union (2010b) 'Europol General Report 2009', Doc. 10099/10, Brussels, 31 May 2010.

Davis Cross, Mai'a (2007) 'An EU Homeland Security? Sovereignty vs. Supranational Order', European Security 16, 1, 79-97.

Deflem, Mathieu (2006a) 'Global Rule of Law or Global Rule of Law Enforcement? International Police Cooperation and Counter-Terrorism', The Annals of the American Academy of Political and Social Science, 603, 1, 240-251.

Deflem, Mathieu (2006b) 'Europol and the Policing of International Terrorism', Justice Quarterly 23, 3, 336-59.

Den Boer, Monica (2002) 'Towards an Accountability Regime for an Emerging European Policing Governance', Policing and Society 12, 4, 275-290.

Den Boer, Monica, Hillebrand, Claudia and Nölke, Andreas (2008): 'Legitimacy under Pressure: The European Web of Counter-Terrorism Networks', Journal of Common Market Studies, 46, 1, 101-24.

Eder, Klaus and Trenz, Hans-Jürgen (2003) 'The Making of a European Public Space: An Inquiry into Relating Supranational Politics and Transnational Spaces of 
Communication: The Case of Justice and Home Affairs', in Linking EU and National Governance, ed. by Beate Kohler-Koch, Oxford: Oxford University Press, 111-134.

European Commission (2002) 'Democratic Control over Europol', Communication from the Commission to the European Parliament and the Council, Doc. COM (2002) 95 final, Brussels, 26 February 2002.

European Commission (2005) 'Strategy on the External Dimension of the AFSJ', Doc. COM (2005) 491 final, 12 October 2005.

European Commission (2007) 'Prevention Of And Fight Against Crime: Annual Work Programme 2008'.

European Commission (2010a) 'The EU Counter-Terrorism Policy: main achievements and future challenges', Communication from the Commission to the European Parliament and the Council, Doc. COM(2010)386 final, Brussels, 20 July 2010.

European Commission (2010b) 'Communication from the Commission to the European Parliament and the Council on the procedures for the scrutiny of Europol's activities by the European Parliament, together with national Parliaments', Doc. $\operatorname{COM}(2010) 776$ final, Brussels, 17 December 2010.

European Council (1999) 'Presidency Conclusions', Tampere European Council, 15 and 16 October 1999.

European Council (2001) 'Conclusions and plan of action of the extraordinary European Council meeting on 21 September 2001', Doc. SN 140/01, Brussels, 21 September 2001.

European Council (2010) 'The Stockholm Programme - An Open and Secure Europe Serving and Protecting Citizens', Doc. 2010/C 115/01, Brussels, 4 May 2010.

European Parliament (2003) 'European Parliament recommendation to the Council on the future development of Europol (2003/2070(INI))', Doc. P5_TA(2003)0186, 10 April 2003.

European Parliament (2009) 'Europol reforms: MEPs criticize Council and demand democratic scrutiny', Press Release.

European Parliament, LIBE Committee (2001) 'Report on the role of the European Union in combating terrorism (2001/2016(INI))', Rapporteur: Graham R. Watson, Doc. A50273/2001 Final, 12 July.

European Parliament, LIBE Committee (2011) 'Working Document on the European Union's internal security strategy', Rapporteur: Rita Borsellino, Doc. PE458.598v01001, 4 February.

European Parliament, Temporary Committee on the alleged use of European countries by the CIA for the transportation and illegal detention of prisoners (2007) 'Report on the alleged use of European countries by the CIA for the transportation and illegal detention of prisoners', Rapporteur: Giovanni Claudio Fava, Doc. A6-9999/2007.

European Report (2005) 'One year from Madrid, EU boosts its anti-terrorism actions', European Report, 9 March 2005.

Europol (2001) 'Agreement between the United States of America and the European Police Office', Council Doc. 14586/01, 6 December 2001.

Europol (2002) 'Supplemental Agreement between the Europol Police Office and the United States of America on the exchange of personal data and related information', 20 December 2002.

Europol (2008) EU Terrorism Situation And Trend Report (TE-SAT), The Hague.

Europol (2009) Annual Report 2008, The Hague.

Federal Parliament of Belgium (2011) 'Presidency Conclusions', Conference of the Speakers of the Parliaments of the EU, Brussels, 4-5 April.

Fidler, Stephen (2011) 'Europol Chief Sees New Roles for Agency', Wall Street Journal, 28 March 2011.

Fijnaut, Cyrille (2002) 'Europol and the parliaments of the member states of the European Union', in From Europol to Parlopol: interparliamentary conference on democratic control of Europol, ed. by Dutch Parliament, Amsterdam: Boom, 15-19. 
General Secretariat of the Council of the EU (2009) 'Background: The Lisbon Treaty's impact on the Justice and Home Affairs (JHA) Council: More co-decision and new working structures', December 2009.

Gerspacher, Nadia and Dupont, Benoît (2007) 'The nodal structure of international police co-operation: an exploration of transnational security networks', Global Governance 13, 3, 347-364.

Gibson, Stevyn (2009) 'Future roles of the UK intelligence system', Review of International Studies 35, 4, 917-928.

Gill, Peter and Phythian, Mark (2006) Intelligence in an Insecure World, London: Polity Press

Guild, Elspeth (2008) 'The Uses and Abuses of Counter-Terrorism Policies in Europe: The Case of the 'Terrorist Lists', Journal of Common Market Studies, 46, 1, 173-93.

Guild, Elspeth and Carrera, Sergio (2005) 'No Constitutional Treaty? Implications for the Area of Freedom, Security and Justice', CEPS Working Document No. 231, Brussels.

Guild, Elspeth and Geyer, Florian (2006) 'Getting local: Schengen, Prüm and the dancing procession of Echternach: Three paces forward and two back for EU police and judicial cooperation in criminal matters', CEPS, Brussels.

Hillebrand, Claudia (2009) The CIA's extraordinary rendition and secret detention programme, European reactions and the challenges for future international intelligence co-operation, Clingendael Security Paper No. 9, March 2009, Netherlands Institute of International Relations - Clingendael, The Hague.

House of Commons (1996) 'Written Answers to Questions', by Home Department, House of Commons Hansard, 11 January 1996, Column 276.

House of Commons, Select Committee on European Union (2011) 'National parliaments' scrutiny of Europol', 9 February 2011, London.

House of Lords, European Union Committee (2011) 'The EU Internal Security Strategy', $17^{\text {th }}$ Report of Session 2010-12, 24 May 2011, London.

Howorth, Jolyon (2008) 'European Security and Counter-Terrorism', in Immigration, Integration, and Security: America and Europe in Comparative Perspective, ed. by Ariane Chebel d'Appollonia and Simon Reich, Pittsburgh: University of Pittsburgh Press, pp. 95-110.

Interview A: Author's interview with an MEP, March 2008.

Interview B: Author's interview with a senior official in the field of EU data protection, April 2008.

Jeffrey-Jones, Rhodri (2007) 'The idea of a European FBI', in Counterintelligence and Counterterrorism, ed. by Loch Johnson, New York: Praeger, 73-97.

Krahmann, Elke (ed.) (2005) New Threats and New Actors in International Security, New York: Palgrave Macmillan.

Loader, Ian (2002) 'Governing European Policing: some problems and prospects', Policing and Society 12, 4, 291-306.

Lodge, Juliet (2004) 'EU Homeland Security: Citizens or suspects?' Journal of European Integration 26, 3, 253-279.

Lummer, Benjamin (2008) 'Disaggregating parliamentary participation: an analysis of different policy fields', in Conference Proceedings 'Fifty Years of Interparliamentary Cooperation: Progressing Towards Effective Cross Level Parliamentarism?', Berlin: Stiftung Wissenschaft und Politik.

McGinley, Marie and Parkes, Roderick (2007) 'Rights vs. Effectiveness? The Autonomy Thesis in EU Internal Security Cooperation', European Security 16, 3, 245 - 266.

Monar, Jörg (2004) 'The EU as an International Actor in the Domain of Justice and Home Affairs', European Foreign Affairs Review 9, 395-415.

Monar, Jörg (2005) 'Anti-terrorism law and policy: the case of the European Union', in Global Anti-Terrorism Law and Policy, ed. by Victor V. Ramraj et. al., Cambridge: Cambridge University Press, 425-52.

Monar, Jörg (2006) 'Cooperation in the Justice and Home Affairs Domain: Characteristics, Constraints and Progress', European Integration 28, 5, 495-509. 
Monar, Jörg (2008) 'Justice and Home Affairs', Journal of Common Market Studies 46, 1 (Suppl.), 109-126.

Morgan, Rod and Newburn, Tim (1997) The Future of Policing, Oxford: Clarendon Press.

Müller-Wille, Björn (2006) 'Intelligence and Democratic Accountability: A Blessing Not a Curse', European Security 15, 4, 491-506.

Occhipinti, John D. (2003) The Politics of EU Police Cooperation: Toward a European $F B l$ ?,Boulder, CO: Lynne Rienner.

O'Toole, Laurence J. Jr. (1997) 'The Implications for Democracy in a Networked Bureaucratic World', Journal of Public Administration Research and Theory 7, 3, 443459.

Peers, Steve (2005) 'Operational Collaboration On Justice, Security and Policing in the Constitutional Framework', in The EU Constitution: The Best Way Forward?, ed. by Deidre Curtin, A.E. Kellermann and S. Blockmans, The Hague: T.M.C. Asser Press, 201-207.

Peirce, Gareth (2009) 'Make sure you say that you were treated properly', London Review of Books 31, 9, 9-14.

Spence, David (ed.) (2007) The European Union and Terrorism, London: John Harper Publishing.

Tsakatika, Myrto (2007) 'A Parliamentary Dimension for EU Soft Governance', European Integration 29, 5, 549-564.

Walker, Neil (2004) 'In Search of the Area of Freedom, Security and Justice: A Constitutional Odyssey', in Europe's Area of Freedom, Security and Justice, ed. by Neil Walker, Oxford: Oxford University Press, 1-37. 